\title{
The Authority of the Regional Supervisory Board on the Notary Protocol Whose Term of Office Has Expired
}

\author{
Vidya Puterci Dramela*; Azmi Fendri; Syahrial Razak \\ Faculty of Law, Universitas Andalas Padang, Indonesia \\ Email: vidyaputerci@gmail.com
}

http://dx.doi.org/10.18415/ijmmu.v6i1.569

\begin{abstract}
Notary is an authorized official who makes authentic deeds as stipulated in article 15 of Law number 2 of 2014 concerning changes to Law number 30 of 2004 concerning the notary term of office. When the authority is granted, the responsibility will be attached to the notary including the retired notary. Even though a notary has retired, his/ her responsibility remains inherent for life for the deed he/ she made when he/ she was an active notary. The research objectives are 1) to find out how the process or procedure for submitting a retired notary protocol, 2) to find out what actions are taken by the regional supervisory board on the retired notary protocol. This research applied an empirical juridical approach; it is the approach to the problem through the research by looking at the norms or provisions of the applicable law. Based on the research findings, the urgency of the authority of the regional supervisory board on the notary protocol that has ended his/ her term of office is that a notary still has the responsibility to submit the notary protocol to the regional supervisory board. The transfer of notary protocol to other notaries can provide a broader scope for the parties in the deed to obtain justice so that a legal certainty is achieved.
\end{abstract}

Keywords: Authority; Notary; Notary Protocol; Term Of Office

\section{Introduction}

Human, as God's creature, has dignity and a higher or lower degree than other God's creatures; it depends on human behavior itself. Behavior, in this case, is not just behavior towards fellow human beings, but also behavior towards nature and the surrounding environment and behavior towards the Creator of human itself. The perfection of human behavior is not just an outer behavior, but also inner behavior; considering that humans are creatures that have both outer and inner dimensions. Both of these dimensions are in human control so that between the two must be sought to achieve harmony (Anshori, 2009).In social life, a person basically has certain views about what is good and what is bad. These views are always manifested in certain pairs. For example, there are pairs of the value of order with the value of peace, the value of public interest with the value of personal interest, the value of sustainability with the 
value of innovation; thus, these value pairs need to be harmonized (Soekanto, 2012). We can see the concrete forms of these pairs in the applicable rules of law in our country.

The rule of law prioritizes outward actions, which are visible actions. In essence, the rule of law is in the soul not in the mind; most importantly and outwardly it should not violate the rule of law (Steiner et al., 2008). People will not be punished or given legal sanctions just because of what they think or what lies in their minds. It means that a person cannot be punished because of something that is thought or occurred in his/ her mind (cogitationis noen patitur). ${ }^{1}$

The law requires human actions to manifest and does not care about the inner attitudes of legal subjects. The will for legal awareness is the longing of the law for the inner atmosphere that exists in humans. The fact also shows it since the arrangement of humans who see their physical side will only cause a kind of restraint on humans themselves; whereas, humans in their nature are free. Human restraint in any way including legal restraint is a defection of man himself and produces what is known as dehumanization or depersonalization. ${ }^{2}$

Notary is a public official authorized to make authentic and other deeds as stated in the Law of Notary Position. Notary is one profession that has an active role in supporting the law enforcement process within the Unitary State of the Republic of Indonesia (Arisaputra, 2012). The existence of a notary in Indonesia is stated in article 1868 of the Civil Code which states that "an authentic deed is a deed which is determined by the Law made by or witnessed by the general employees in charge where the deed is made".In this regard, in 2004, Law Number 30 of 2004 concerning Notary Position (in lieu of Staatblad 1860 Number 30) was subsequently amended by Republic of Indonesia Law Number 2 of 2014 concerning Amendment to Law Number 30 of 2004 concerning Notary Position; henceforth in this paper abbreviated with the Law of Notary Position (UUJN).

The authority held by a notary requires continuity to seek legal certainty for all parties. However, the juridical age of a notary is limited by the Law as stipulated in Article 8 paragraph (1) letter b Number 2 of 2014 concerning UUJN. The article stipulates the term of office of a notary. When the notary is 65 years old it can be extended to 67 years. Therefore, a notary who has entered retirement has an obligation to submit a protocol to another notary appointed by the Regional Supervisory Board (MPD); as contained in Article 62 letter b of UUJN Number 30 of 2004 concerning the reason for submitting a notary protocol. Article 1 Number 2 of 2014 UUJN, number 13 states that the protocol is a collection of documents that are state records and must be kept and maintained by a notary. This study is conducted to analyze the notary protocol of a notary who will enter retirement age, as stipulated in Article 62 of Law Number 30 of 2004 concerning Notary Position, and procedures for submitting notary protocols as regulated in Article 63 of Law number 2 of 2014 concerning the amendment to Law Number 30 of 2004, i.e. the obligation of the notary to submit the notary protocol to MPD. The authority of the MPD is contained in the Regulation of the Minister of Law and Human Rights of the Republic of Indonesia Article 23 number 40 of 2015 concerning Organizational Structure, Procedures for Appointment of Members, Procedures for Dismissal of Members, and Procedures of the Supervisory Board.

Further regulation of retired notaries is regulated in the Republic of Indonesia Minister of Law and Human Rights Regulation Number 25 of 2014. The interesting point here is that the reality that occurs in the community is that not all of these notaries can understand the procedure for submitting notary protocols and want carry out the obligation to submit the notary protocol to other notaries both appointed by the notary or appointed by MPD. Thus, the society, especially the parties involved in the deed, is confused in seeking legal certainty. Indirectly, it can cause enormous material losses to the people

\footnotetext{
${ }^{1}$ Sudikno Mertokusumo in Wawan Muhwan Hariri, 2012, Pengantar Ilmu Hukum (Introduction to Law), Pustaka Setia, Bandung, page 32.

${ }^{2}$ Abdul Ghofur Anshori, 2009, Lembaga Kenotariatan Indonesia (Indonesian Notary Institution), UII Press, Yogyakarta, page 3.
} 
who need a deed previously made to a notary who has entered retirement age. The purpose of supervision of the notary is that the notary as much as possible meets the requirements demanded of him/her. ${ }^{3}$ The requirements demanded are not only by law or law, but also based on the trust given by the client to the notary. ${ }^{4}$

Regarding the presence of notary institutions in Indonesia, supervision of notaries has always been carried out by judicial institutions and the government. The purpose of the supervision is so that the notaries in carrying out their duties fulfill all the requirements relating to the implementation of the duties of the notary position, in order to safeguard the interests of the society. It is not only for the sake of the notary himself/ herself, but also for the sake of the society he/ she serves. ${ }^{5}$ Another purpose of supervision of the notary is that the notary is presented to serve the interests of the people who need evidence in the form of authentic deeds. ${ }^{6}$ Thus, a notary with full awareness and responsibility in his/her job duties follows or is based on applicable law. ${ }^{7}$

This is inseparable from the role of the society in monitoring and always reporting the actions of notaries who in carrying out their duties are not in accordance with applicable legal rules to the local Notary Supervisory Board. ${ }^{8}$ The purpose of supervision is not only intended for structuring the notary code of ethics but also for broader purposes; so that notaries in carrying out their duties fulfill the requirements stipulated by law in order to safeguard the interests of the people they serve.

\section{Theoretical Framework}

\subsection{Legal Responsibility Theory}

The legal responsibility theory is a theory that analyzes the responsibilities of legal subjects or actors who have committed acts against the law or criminal acts to bear costs or losses or carry out crimes for their mistakes or because of their negligence (Salim and Nurbani, 2013). In Indonesian, the word responsibility means that the condition must bear everything (if something happens, then someone may be sued, blamed, brought to justice, etc.). Bears are defined as being willing to bear the costs (managing, maintaining), guaranteeing, stating the state of willingness to carry out obligations. ${ }^{9}$

Kelsen (2017), in his theory of legal responsibility, states that "a person is legally responsible for a certain act or that he or she bears legal responsibility; the subject of the law means that he/ she is responsible for a sanction in the event of a contravention (Kelsen, 2007). Furthermore, Hans Kelsen stated that "failure to exercise caution which is required by law is called negligence. In addition, oversight is usually seen as one other type of error (culpa), although it is not as severe as the mistakes that are fulfilled because of anticipating and wanting, with or without evil intentions or harmful consequences." 10

Obligations for everything or functions accept imposition as a result of the actions of themselves or other parties. Whereas, the understanding of responsibility according to the Big Indonesian Dictionary is a condition that must bear everything (if something happens, then someone may be sued, blamed, brought to justice, etc.). According to the legal dictionary, there are 2 (two) terms of responsibility, i.e. liability (the state of being liable) and responsibility (the state or fact being responsible).

\footnotetext{
${ }^{3}$ G.H.S Lumban Tobing, Op.Cit, page 301.

${ }^{4}$ Ibid.

${ }^{5}$ G.H.S Lumban Tobing, Op.cit, page 301.

${ }^{6}$ Habib Adjie, Majelis Pengawas Daerah (Regional Supervisory Board), page 3.

${ }^{7}$ Ibid.

${ }^{8}$ Habib Adjie, Sanksi Perdata \& Administrasi (Civil \& Administrative Sanctions), page 129

${ }_{9}^{9}$ Departemen Pendidikan dan Kebudayaan (Department of Education and Culture), 1989, Kamus Besar Bahasa Indonesia (Indonesia Dictionary), Jakarta: Balai Pustaka), page 899.

${ }^{10}$ Hans Kelsen, Ibid.
} 
The function of the theory in this study is to provide direction or instructions and explain the observed symptoms. Therefore, this study is directed to the applicable positive law; i.e. the notary obligation in terms of not being fulfilled the provisions of Article 62 of Law Number 30 of 2004 and Article 63 of Law Number 2 of 2014 concerning Notary Position.

\subsection{Legal Certainty Theory}

Basically, law is essentially an abstract matter, even though its manifestations are concrete. People's perception of the law is diverse; depending on which angle they look at (Spyke, 1998). Judges will view the law from their point of view as judges, legal scientists will view the law from the point of their scientific profession, common people will view the law from their perspective and so on. Legal certainty is a question that can only be answered normatively, not sociologically. Normative legal certainty is when a regulation is defined and promulgated because it regulates clearly and logically (Braithwaite, 2002). Obviously, in this case, it does not cause doubt (multi-interpretation) and logically is that it becomes a norm system with other norms so that it does not clash or does not cause norm conflicts.

\subsection{Authority Theory}

Theoretically, the authority derived from the legislation is obtained through three ways, i.e. attribution, delegation and mandate. Regarding the three sources of authority, the discussion of this study uses the authority of the delegation in which a delegation of authority by the government occurs attributively to the agency or other State Administration Office (Admosudirjo, 2001). Influencing component is the use of authority intended to control the behavior of legal subjects, the basic legal component means that the legal basis of the authority must always be able to be appointed, and legal component means that there are standards of authority (all types of authority) and special standards (for certain types of authority).In this paper, the concept of authority is only limited to the authority of the government (bestuurbevoegdheid). The scope of government authority not only includes the authority to make government decisions (besluit), but also all authority in order to carry out their duties (Adegustara, 2005). Authority has an important role in running the government, in which it contains rights and obligations in a public legal relationship.

\section{Research Method}

This research is an analytical descriptive research that is describing and explaining the object of the study in a complete, clear and objective manner that relates with problems (Denzin and Yvonna, 2008). In this study, the authors describe how the role of the Regional Supervisory Board in the supervision of the notary protocol whose term of office has expired in Padang City.In this study, primary data was obtained directly in the field through interviews with respondents; i.e. notaries. Secondary data is data obtained from legal materials. The data needed in legal research is obtained by using data collection techniques; i.e. literature studies and interviews (Brinkmann, 2014).

In this study the processing of the data obtained after the study was carried out by editing and coding. Editing is the process of reviewing the records, files, information collected by data seekers that are expected to improve the quality of reliability of the data to be analyzed. In the coding process, after editing, it is given certain signs or codes to determine the relevant or required data.Data analysis was conducted using juridical qualitative; i.e. a description of the data analyzed based on legislation and the opinions of experts then presented with the sentence that has been previously analyzed. After that, the next step is to interpret and draw conclusions according to the issues being discussed (Kleining and Harald 2001). 


\section{Findings And Discussion}

\subsection{Process or Procedure for Submission of the Notary Protocol whose Term of Office has been Expired}

In carrying out the profession, some notaries practically experience the protocol submission to other parties caused by death, end of term of office, self-request, spiritual and/or physical incapability, appointed as state official, relocated, dismissed temporarily or dishonorably.Each deed made by a notary must be carefully arranged, neat and not careless, because the deeds are included in the notary protocol. Article 1 number 13 UUJN states that what is meant by the Notary Protocol is a collection of documents (state records) that must be stored and maintained by a notary in accordance with the provisions of the law.Based on the above paragraph, the formula listed in Article 1 number 13 of Law Number 2 of 2014 concerning Amendment to Law Number 30 of 2004 concerning Notary Position is wider than the formula stated in Law Number 30 of 2004 concerning Notary Position. The formulation contained in Article 1 number 13 of Act Number 2 of 2014 concerning Amendment to Law Number 30 of 2004 concerning Notary Position is added by: "in accordance with the provisions of the law". Thus, the elements listed in the notary protocol include:
a. Collection of documents
b. State archives;
c. One who stores and maintains; and
d. In accordance with the provisions of the law.

Submission of a notary protocol is carried out if a notary:

a. Die;

b. Come to the end of his/her term of office;

c. Propose self-request;

d. Has spiritual and/or physical incapability of carrying out office duties as a notary continuously for more than 3 (three) years;

e. Is appointed as state official;

f. Is moved to other office area;

g. Is temporarily dismissed; or

h. Is dishonorably dismissed.

In addition to these reasons, this study focuses on letter $b$ about the term of office that has ended as stipulated in Article 8 paragraph (1) and Article 8 paragraph (2) of Law Number 2 of 2014 concerning Notary Position. This Article regulates the expiration of the notary's term of office when the notary is 65 (sixty-five) years old, which can be extended to the age of 67 (sixty-seven) years. The notary must inform MPD manually or electronically about the expiration of his/her term of office and at the same time propose another notary as the protocol holder. The notification must be submitted in a minimum of 180 (one hundred and eighty) days or no later than 60 (sixty) days before the notary reaches the age of 65 (sixty-five) years accompanied by supporting documents.

This is stipulated in Article 46 of the Regulation of the Minister of Law and Human Rights Number 25 of 2014 concerning Terms and Procedures for Appointment, Transfer, Dismissal and Extension of Term of Office of Notaries, hereinafter referred to as Regulation of the Minister of Law and Human Rights Number 25 of 2014. Therefore, a notary who has entered retirement must submit the notary protocol to another notary who has been appointed by the Regional Supervisory Board (MPD), as contained in Article 62 of the UUJN regarding the reason for submitting the notary protocol. With the expiration of the term of office, the notary must submit a notary protocol which includes: 
a. Notarial deed;

b. Book listing deed or repertories;

c. Book listing deeds under the acknowledgement of the signatory made before a Notary or deed under the acknowledgement of registered parties;

d. Book listing names of the viewers or the preceptors;

e. Book listing protests;

f. Book listing wills;

g. Another list book that must be kept by a notary based on the provisions of the law.

The process of transferring the protocol is as follows: ${ }^{11}$

a. The notary concerned reports to the MPD to submit a move to other work area and also appoints the relevant notary who will accept the protocol. Then, MPD conducts a meeting with other MPD members and decides that the relevant notary will move his/her work area, then the relevant notary must show a Certificate. MPD will then reply to the report stating that the MPD agrees as long as the protocol recipient is willing to accept the protocol.

b. After that, MPD makes the report to hand over the two parties who will provide and accept the notary protocol. The handover was carried out and signed in front of MPD. Before MPD signs the Case Report (BAP), the MPD must send a letter to the recipient of the protocol that the recipient of the protocol agrees which is witnessed by the chairperson of the MPD, MPD representatives and members.

c. If a Notary died, the family must write to the MPD that the Notary has died. MPD meetings and appoints a Notary in the area by sending a letter of appointment whether the notary is willing to accept the protocol in which the deceased notary and the notary may not refuse.

d. After the above procedure is carried out, the MPD must report to the Central Supervisory Board (MPP) for approval by MPP.

A number of notaries seemed confused about how and where to keep the notary protocol as mandated in Law Number 2 of 2004 concerning Amendment to Law Number 30 of 2004 concerning Notary Position. Article 1 number 13 of the Notary Position defines the notary protocol as a collection of documents that must be stored and maintained by a notary public in accordance with the provisions of the law. As a state archive, the document must always be stored and maintained under any circumstances even if the notary of the owner of the protocol is on leave or dies. Based on Law Number 2 of 2004 concerning the notary position, the notary protocol is not always held by a notary who has received the designated protocol. Article 63 paragraph (5) of UUJN states that the notary protocol from other notaries which at the time of submission is 25 (twenty-five) years or more is submitted by the protocol recipient notary to the Regional Supervisory Board (MPD), which means that protocol recipient notary submits notary protocol he/she receives from other notary protocol when the protocol is 25 years old to MPD.

According to the MPD function, Regulation of Minister of Law and Human Rights of the Republic of Indonesia Number M.HH-06.AH.02.10 of 2009 concerning the Notary Supervisory Board Secretariat Article 6 letter f concerning "the Storage of Notary Protocol aged 25 years or more", there is an MPD responsibility in the storage of the notary protocol that is 25 years or older. However, this rule is not implemented especially in Padang City. The 25-year-old notary protocol is still held and stored by the notary recipient of the protocol without being submitted to the MPD and vice versa MPD does not request the protocol.

\footnotetext{
${ }^{11}$ Interview to Desmawita, SH., MPD member of Padang City, on July 5, 2018, at 13.00 West Indonesia Time.
} 
Based on research conducted by the authors on June 22, $2018^{12}$ in the office of the Ministry of Law and Human Rights in the Public Service Division where the Regional Supervisory Board (MPD) is located, there are several notaries who hold protocols that are 25 years or older. From those Notaries, one of them is Notary Desrizal Idrus Hakimi, SH, with the Appointment Decree C-196HT.03.01-Th 2001 dated April 4, 2001 and Notary Syamsuhardi, SH, with the Appointment Decree C-375.HT.03.01-Th 1998 dated October 14, 1998.

Submission of protocol from a notary who has ended his/her term of office is carried out through several stages. Based on the interview that the authors did with Notary Desrizal Idrus Hakimi, ${ }^{13}$ the stages of submission of the notary protocol include: appointment of protocol recipients notary, reporting on protocol submission, and data collection of the deeds and documents to be submitted.Notary Desrizal mentioned $^{14}$ that after Notary Yenita Asmawel reported to the Ministry of Law and Human Rights and MPD, the data was collected on the protocol to be submitted to him. This data collection was carried out by Desrizal Notary assisted by his staff. Notary Desrizal examined deeds and deed books one by one which were part of the protocol. Since Yenita Asmawel's Notary protocol is very much, it takes more than 1 (one) month to collect the protocol. To avoid errors in data collection, it must be carried out carefully.

It was different from Yenita Asmawel's Notary protocol, data collection on the Notary Z protocol was carried out after the appointment letter and capable certificate from the MPD was issued. This data collection was carried out by Notary $\mathrm{Z}$ as the owner of the protocol. Before moving to other work area, Notary Z had collected data on the protocol assisted by several staff members. Notary Z's protocol is not too much compared to Notary Yenita Asmawel's protocol.

\subsubsection{Making Protocol Submission Report}

Reports may be made by a notary who will submit or receive the protocol. It is recommended that the person making the report to conduct the data collection on the protocol. Regarding Notary Yenita Asmawel's protocol, Notary Desrizal is a person who conducts data collection and also makes the report. It was the same as Notary S, he also did the data collection and at the same time made the report. This handover was also witnessed by 2 (two) witnesses who were usually taken from the employees of the notary concerned. After that, the witnesses also signed in the report of the protocol submission. The signing of the handover report was held at the notary office of the protocol owner. Regarding Notary Yenita's protocol, the signing was held at the Notary Desrizal office and was attended by Notary Desrizal and 2 (two) witnesses of Notary Yenita's employees.

In this case, the process of submitting the notary protocol, according to Notary Desrizal, due to the fact that at the time of protocol submission, MPD in Padang City had not been active and had no clear office. Therefore, the submission of the protocol was only carried out without witnessing by MPD. Desrizal Idrus ${ }^{15}$ confirmed that in the 2 years of its formation, the MPD itself had not been active in exercising its authority as stipulated in the UUJN. MPD was formed after the birth of UUJN; i.e. in 2004. However, it was only effective around 2007.According to one MPD member ${ }^{16}$ from the government element, related to the presence of the MPD in the notary protocol submission program, there is an obligation from the MPD to attend and witness the process of signing the submission protocol report

\footnotetext{
${ }^{12}$ Results of the Interview with the Chairperson of the Indonesian Notary Association of West Sumatra on June $20,2018$.

${ }^{13}$ Interview with Notary Desrizal Idrul Hakimi, S.H., as Notary and PPAT of Padang City as the recipient of the 25-year-old Notary Protocol, on June 20, 2018 at 17.00 West Indonesia Time.

${ }^{14}$ Interview with Notary Desrizal Idrul Hakimi, S.H., as Notary and PPAT of Padang City as the recipient of the 25-year-old Notary Protocol, on June 20, 2018 at 17.00 West Indonesia Time.

${ }^{15}$ Interview with Desrizal Idrul on July 6, 2018 at 17.00 West Indonesia Time.

${ }^{16}$ Interview with one of the Padang City MPD members from the government element, on July 4, 2018, at 15.00 West Indonesia Time.
} 
which MPD is only the witness party. Before the submission takes place, the MPD has been initially notified and agreed to the matter.

\subsubsection{Implementation of Protocol Transfers}

After the protocol is handed over, the transfer of the deed protocol from the protocol office to the receiving protocol office is carried out. After signing the protocol submission report, since then, the responsibility for storing the notary protocol has been transferred from the notary owner of the protocol to the notary recipient of the protocol.

\subsubsection{Reporting and Submission of Protocol Submission Report}

According to Notary Desrizal ${ }^{17}$, at that time, MPD Kota Padang was not yet active in carrying out its authority. Notary is a profession that will not be carried out for life, just like some other professions that also have term of office. The reasons for the termination of the notary's term of office are regulated in Article 8 where the clarity of the notary retirement age is clarified and strengthened by the Honorary Assembly through the rejection of the material test of article 8 paragraph (1) letter b and paragraph (2) of Law Number 30 of 2004 concerning Notary Position. The article itself regulates the pension limit for a notary at the age of 65 which can be extended for 2 years.

According to Hakim M Alim, regarding the age of retirement or the end of term of office in all agencies, it has been regulated in the laws and regulations. The Honorary Council refers to the age limit for constitutional judges when they reach the age of 67 or can be re-elected once after a term of 5 years has ended. In addition, these restrictions also apply to Supreme Court Justices who retire at the age of 65 and can only be extended to 67 years of age.Based on the results of interviews with one of the notaries in Padang City who will extend the retirement age, the notary has prepared everything as the condition for submitting a notary term extension from age 65 to age 67 . The notary with the initials SD made a letter of application to the minister of Director General by attaching the following documents:
a. Certificate of health
b. Certificate of spiritual/mental health
c. Recommendation from the regional supervisory board
d. Recommendation from the area supervisory board
e. Recommendation from the central supervisory board
f. Recommendation from the regional administrator
g. Recommendation from the area administrator
h. Recommendation from the management of the notary Indonesian bond center.

According to SD, the application for the submission of a notary's term of office extension from age 65 to age 67 must be submitted 180 days or at the latest 90 days before the notary who will apply for the extension of that age enters the age of 65 years. For the extension of the pension period, the Ministry of Law and Human Rights launched an online service application for notaries who will apply for pensions for those who are 65 years old and for notaries who will extend their term of office to 67 years. It is done by going to the retirement term application page to fill in data about the notary profile. A retired notary must submit it online when he/she has entered the age of 64 years 10 months. If until the age of 65 he has not yet applied for a retirement, then the service on the AHU online site automatically clicks the stop button. For a notary who will extend the term of office from the age of 65 to 67 years, he/she must meet the requirements for notary extension terms including:

\footnotetext{
${ }^{17}$ Interview with Notary Desrizal Idrul Hakimi, S.H., Notary and PPAT of Padang City as the recipient of the 25-year-old Notary Protocol, on June 20, 2018 at 17.00 West Indonesia Time.
} 
a. The original certificate of health that contains the results of the overall physical health examination from a state or private hospital

b. The original certificate of spiritual/mental health from a psychiatrist or a state or private hospital

c. The original recommendation from the regional supervisory board (MPD)

d. The original recommendation from the area supervisory board (MPW)

e. The original recommendation from the central supervisory board (MPP)

f. The original recommendation from the regional management of notary organization

g. The original recommendation from the area management of notary organization

$\mathrm{h}$. The original recommendation from the central management of the notary organization

Furthermore, the authors will discuss the process of submitting a notary protocol submitted no later than 30 (thirty) days by making a notary protocol submission report signed by the party who submit and receive the protocol. Meanwhile, Article 63 to Article 65 of Law Number 2 of 2014 has determined the parties that submit and receive the notary protocol.

In Article 63 paragraph (4) of UUJN, MPD can determine or appoint a notary who will accept the protocol. However, practically, many notaries do not want to accept other notary protocols despite the fact that a notary may not reject other notary protocols. The notary's responsibility for the notary protocol that has not been submitted to another notary in this case can be categorized as illegal. Unlawful acts here are broadly interpreted as an act that not only violates the Law but also violates propriety, decency or the rights of others and can cause harm. This also happened in Pariaman, where a notary who has entered retirement did not submit the protocol to MPD to be submitted to another holder of notary protocol because the retired notary forgot his/her obligations as a retired notary. Thus, MPD takes the notary protocol to be able to appoint and submit it to the other holder of notary protocol.

A notary who has entered the age of 65 (sixty-five) years which holds a number of protocols is not small. As previously explained, the notary protocol that has passed away must be submitted to another notary through his/her heir. The notary who has entered the age of 65 (sixty-five) years must submit the protocol to other notary protocol holder. However, the notary protocol requires a large storage area. In this case, there are some notaries who have been appointed as protocol holders refusing to keep the protocol for certain reasons. This is where the decisiveness of MPD is needed regarding the process of submitting and storing notary protocols that have entered the age of 65 (sixty-five) years or died so that it runs in accordance with regulations. Furthermore, the MPD will propose to the notary where the protocol will be submitted based on the results of the MPD meeting. The decision from the results of the meeting will be a proposal to the Ministry of Justice and Human Rights, and the Ministry on behalf of the Minister will issue a decree to appoint protocol holders.

The authors in this study found that there were some notaries who did not fulfill the obligation to report and submitted the notary protocol that had passed the time period determined by law as contained in Article 63 paragraph (6) of the UUJN. In this case, the MPD gives a reprimand and submits a notification to the notary to take the available protocol belong to that notary. This case occurred in two places, i.e. Padang and Pariaman. The two cases that the authors found occurred before 2014.

Based on the results of the authors' interview with one of the MPD employees, after the incident, MPD corrected and supervised the notary who will retire by visiting the notary's office to check everything related to the performance of the notary.

For this submission, the MPD protocol submission report will be made by the MPD which will later be signed by the parties who submitted and received the protocol. Based on the Submission Report that has been signed, MPD will report to the Ministry of Law and Human Rights to make a Decision Letter of submission of the notary protocol from retired notaries to MPD. If the deed and all documents to 
be submitted by a notary entering retirement to the MPD have a very large number, then it will only be symbolically handed over by several deeds and documents.

\subsection{Process or Procedure for Submission of the Pension Notary Protocol}

Basically, the authorized party to supervise and inspect notaries is the Minister of Law and Human Rights in which the Minister practically formed a Notary Supervisory Board. Article 35 of the Presidential Regulation Number 9 of 2005 concerning Position, Task, Function, Organizational Structure and Work Procedure of the State Ministries of the Republic of Indonesia states that the Minister as head of the Department of Law and Human Rights has the task of assisting the President in carrying out part of government affairs in the field of Law and Human Rights.

The Notary Supervisory Board is the only institution authorized to supervise and inspect and impose sanctions on notaries; in this case, each level of the Supervisory Board (MPDN, MPWN and MPPN) has their respective authority. MPDN's authority is regulated in UUJN, Regulation of the Minister of Law and Human Rights of the Republic of Indonesia Number M.02.PR.08.10 of 2004, and Decree of the Minister of Law and Human Rights of the Republic of Indonesia Number M.39-PW.07.10 of 2004. The term of office of the Regional Supervisory Board member is 3 (three) years from the appointment as referred to in Article 69 paragraph (4) of the UUJN. The Notary Supervisory Board consists of 9 (nine) people among others:

1 (one) Chairperson concurrently member, 1 (one) Deputy Chairperson concurrently member, and 7 (seven) members. The Chairperson and Deputy Chairperson are elected from and by members carried out by deliberation or voting which are then regulated that MPN is assisted by 1 (one) secretary or more appointed at the Notary Supervisory Board meeting. This is confirmed in the Regulation of the Minister of Law and Human Rights of the Republic of Indonesia Number M.02.PR.08.10 of 2004, Article 11 and Article 12.

Supervision and inspection of notaries is carried out by the Supervisory Board, in which there is the element of the notary. Thus, at least the notary is supervised and examined by members of the Supervisory Board who understand the world of notaries. The members of the Supervisory Board from the notary public are internal controls which means it is carried out by fellow notaries who understand the outer and inner world of notaries. Meanwhile, other elements are external controls that represent the academic world, government, and society. Thus, this becomes a complete mix in guaranteeing the effectiveness of supervision of the notary. ${ }^{18}$

The implementation of guidance for notaries by MPDN in this case in collaboration with Regional INI of Padang City is in the form of: ${ }^{19}$

a. Socializing Legal Entity Administration System (SABH), regarding online Fiduciary, Limited Company, Foundation, Testament Monthly Registration and Report;

b. Socializing UUJN;

c. Conducting seminars and legal discussions.

MPDN Kota Padang has carried out periodic checks on notary protocols on a regular basis; i.e. every year and at certain times as necessary, as well as conducting guidance annually on notaries held together with Regional INI of Padang City.Notary examination referred to Article 70 letter b UUJN and Article 16 paragraph (1) Regulation of the Minister of Law and Human Rights of the Republic of Indonesia Number

\footnotetext{
${ }^{18}$ Habib Adjie, Sanksi Perdata \& Administrasi (Civil \& Administrative Sanctions). Op.Cit, page 130.

${ }^{19}$ Interview with Notary Desrizal Idrus Hakimi, SH as a member of the INI Regional Management of West Sumatra, on Saturday, May $28,2018$.
} 
M.02.PR.08.10. In 2004, MPDN has the authority to periodically examine the notary protocol 1 (one) times in 1 (one) year or at any time deemed necessary.

Before carrying out the task of examining the notary protocol, MPDN initially forms an Examination Team consisting of 3 (three) elements; i.e. 1 (one) person from the government, 1 (one) person from a notary, 1 (one) person from academia and assisted with 1 (one) secretary. This Examining Team is incidental; for annual checks or at any time formed by MPDN if necessary.Notary Protocol Examination is carried out periodically every year and every time needed, as stipulated in Article 15 of the Republic of Indonesia Minister of Law and Human Rights Regulation Number M.02.PR.08.10 of 2004. Before conducting an MPDN inspection, it initially notifies the notary no later than 7 (seven) working days before the inspection is conducted. In the notification letter, the hours, days, inspection dates and composition of the names of the examining team will be included. The examination team consisting of 3 (three) people came from each element which later will be assisted by 1 (one) secretary. In examining the notary protocol, commonly, every inspection of the notary protocol, the inspection team will be firstly formed. ${ }^{20}$

Based on the results of research in the field, there have been 2 (two) examinations of the notary protocol, i.e. in 2014 and 2015. Examinations were not notified by proper notices, as stipulated in Article 15 paragraph (1) and paragraph (2) of Ministerial Regulation Law and Human Rights of the Republic of Indonesia Number M.02.PR.08.10 of 2004. However, notices are made through social media by notaries who serve as MPDN members informing that there will be an examination of the notary protocol. Thus, notaries who are domiciled in Padang City must prepare themselves and their offices and all notary protocols that will later be examined by MPDN. This seems like a sudden inspection of the notary protocol. Most respondents objected this because they were not prepared for the notary protocol examination. In addition, when the inspection is carried out, they might not be in their place or office. So, the inspection team is only served by his/her employees. According to Notary Yusmarni, S.H, if the Notary is not in his/her place or office during the examination, then the inspection team should not examine the protocol, even if it is represented by its employees, because the notary's responsibility is to maintain the confidentiality of his/her notarial act. ${ }^{21}$

An examination of the notary protocol shows that, not all of the notaries in Padang City can be visited and inspected periodically or routinely every year by MPDN Kota Padang. In 2015, they could only be visited by the inspection team as much as $40 \%$ (forty) percent. It means that it is less than a part of the number of Notaries in Padang City that can be examined. According to the statement of one of the notaries with the initial M who is also an MPDN member of Padang City for the period 2016 to 2018, this is also due to: ${ }^{22}$

a. A large number of notaries;

b. The extent of the area which is the authority of MPDN Padang City which includes Padang City, Pariaman City, Padang Pariaman Regency, Pesisir Selatan Regency, and the Mentawai Islands and;

c. They hold structural positions at the university, so MPDN members have not yet been able to fully review the notary offices in Padang City.

Guidance from MPDN which is routinely carried out 1 (one) time in 1 (one) year, errors, and deficiencies can be corrected by the concerned notary. In addition, in 2015, and when the authors conducted research and interviews in 2018, several notaries had complied with and corrected these shortcomings. With supervision and guidance carried out by the inspection team regularly every year, the inspection team immediately notifies the submission of a copy of the list of deeds and other lists at the

\footnotetext{
${ }^{20}$ Interview with Ms. Diana Siska, SH, MPD Member of Padang City, on Monday, June 27, 2018.

${ }^{21}$ Interview with Ms. Notary Yusmarni, SH on Monday, June 13, 2018.

${ }^{22}$ Interview with Notary M, MPD Member of Padang City, on Monday, June 13, 2018.
} 
MPDN secretariat in Padang City in the public service division, the regional office of the West Sumatra Legal and Human Rights. In 2016, the submission of a written copy of the list of deeds and other lists tended to increase. ${ }^{23}$

It means that the notary's awareness of his/her obligation to complete the notary protocol is good. Furthermore, during the guidance, MPDN should emphasize to the notary the importance of preparing the other lists as intended as part of the completeness of the notary protocol.The notary protocol that is 25 (twenty-five) years or more in the storage of a notary, in accordance with Article 63 paragraph (5) of the UUJN, should be submitted to MPDN by the holder of notary protocol. If it is not submitted within 30 (thirty) days, MPDN has the authority to take the notary protocol from the notary storage. In 2014 and in 2015 , the inspection team that carried out guidance and supervision in notary protocol inspection periodically 1 (one) time in 1 (one) year, stated that there was no notary protocol aged 25 (twenty-five) years or more at the examined storage of a notary. With the guidance and supervision by the examining team in notary protocol checks that are carried out routinely every year, they have carried out their duties and do not forget to ask about the age of the notary protocol that is 25 (twenty-five) years or more to each notary in Padang City who is the holder of another notary protocol.

By examining the notary's office, the inspection team advises notaries to send or deliver their monthly reports to the MPDN Padang City secretariat in the West Sumatra Office of Law and Human Rights. Then the inspection team makes an Inspection Report signed by the chairman and the notary concerned, as many as 5 (five) copies for the MPDN, MPWN, and MPPN requirements. The Regional Administrators and the Notary are regulated in Article 17 of Ministerial Regulation Number M.02.PR.08.10 of 2004 concerning procedures for the appointment of members, dismissal of members, organizational structure, and examination procedures for the notary supervisory board.

The results of notary protocol examination will be given to the notary, so that future examinations will be made more in accordance with the results of the assessment and the contents of the suggestions included in the results of the examination.

The results of the examination include 4 (four) categories, as follow: ${ }^{24}$
a. Excellent;
b. Good;
c. Poor, and;
d. Bad.

Scores and suggestions given by MPDN in the implementation of guidance and supervision of protocol checks that are routinely carried out every year is intended so that in the periodic subsequent examination, the notaries pay more attention and do not repeat the same mistakes so that maintenance of the notary protocol and neatness of office administration can be improved.Thus, the notary also respects the existence of MPDN which has the authority to conduct supervision, inspection and guidance of the notary itself. If there is a notary who does not care about the advice from the results of the inspection of the protocol for up to 3 (three) times, the MPDN will make a report for sanctions by MPWN. Until the completion of the research at the MPDN secretariat in Padang City, there has been no attempt to impose sanctions by MPWN on reports made by MPDN, because in the 3rd year (three) that coincided with this 2016, it has not carried out notary protocol examination. If it is associated with the authority and supervision theories, the authority to supervise attribute notaries belongs to the Minister of Law and Human Rights of the Republic of Indonesia, who was created and ordered in the law as referred to in Article 67 paragraph (1) of UUJN.

\footnotetext{
${ }^{23}$ Interview with Ms. Desmawita, SH, MH. Public Services Section, at the MPD Office in Padang City on Monday, June $20,2018$.

${ }^{24}$ Interview with Ms. Desmawita, SH, MH. Public Services Section, at the MPD Office in Padang City on Monday, June $20,2018$.
} 
The position of the minister is an executive (government) who exercises government authority in qualifications as a State Administration Agency. Based on Article 67 paragraph (2) of the UUJN, the Minister delegates the supervisory authority to an agency under the name of the Supervisory Board. The Supervisory Board according to Article 1 paragraph (1) of the Regulation of the Minister of Law and Human Rights of the Republic of Indonesia Number M.02.PR.08.10 of 2004, is an entity that has the authority and obligation to carry out supervision and guidance of notaries. Thus, ministers are delegate giver and the Supervisory Board is a delegate. The Supervisory Board, as a delegate, has the authority to supervise the notary completely, without the need to return his authority to delegate giver.

\section{Conclusion}

The process of submitting the notary protocol must go through a letter of application addressed to the Minister of Director General within 180 days before the notary ends the term of office and must submit to MPD both manually and electronically by attaching supporting documents. In addition, MPD prepares a notary protocol submission report designated by the MPD and signed by the parties who submitted and received it.The Regional Supervisory Board conducts guidance and supervision of notaries both preventively and curatively to achieve an ideal practice and supervision in the process of submitting a notary protocol that has expired. So, it can avoid violations of the notary's position.

\section{References}

Adegustara, F. (2005). Hukum Administrasi Negara. Padang: Universitas Andalas.

Admosudirjo, P. (2001). Teori Kewenangan. Jakarta: PT Rineka Cipta.

Anshori, A. G. (2009). Lembaga Kenotariatan Indonesia. Yogyakarta: UII Press.

Arisaputra, M. I. (2012). "Kewajiban Notaris Dalam Menjaga Kerahasiaan Akta Dalam Kaitannya dengan Hak Ingkar Notaris." Perspektif 17(3), 173-183.

Braithwaite, J. (2002). Rules and principles: A theory of legal certainty. Austl. J. Leg. Phil., 27(47).

Brinkmann, S. (2014). Interview. In Encyclopedia of critical psychology (pp. 1008-1010). New York: Springer.

Denzin, N. K., \& Lincoln, Y. S. (2008). Strategies of qualitative inquiry (Vol. 2). Sage.

Departemen Pendidikan dan Kebudayaan. Kamus Besar Bahasa Indonesia. Jakarta: Balai Pustaka, 1989.

Kelsen, H. (2017). General theory of law and state. Routledge.

Kelsen, H. (2007). Pengantar Teori Hukum. Jakarta: Kompas.

Kleining, G., \& Witt, H. (2001). Discovery as basic methodology of qualitative and quantitative research. In Forum Qualitative Sozialforschung/Forum: Qualitative Social Research (Vol. 2, No. 1).

Peraturan Menteri Hukum dan Hak Asasi Manusia Republik Indonesia Nomor 25 Tahun 2014 tentang Syarat dan Tata Cara Pengangkatan, Perpindahan, Pemberhentian, dan Perpanjangan Masa Jabatan. 
Peraturan Menteri Hukum dan Hak Asasi Manusia Republik Indonesia Nomor 40 Tahun 2015 tentang Susunan Organisasi, Tata Cara Pengangkatan Anggota, Pemberhentian Anggota dan Tata Kerja Majelis Pengawas.

Salim, H.S., \& Nurbani, E.S. (2013). Penerapan Teori Hukum Pada Penelitian Disertasi dan Tesis, Buku Kedua. Jakarta: Rajawali Pres.

Soekanto, S. (2012). Faktor-Faktor Yang Mempengaruhi Penegakan Hukum. Jakarta: Raja Grafindo Perkasa.

Spyke, N. P. (1998). Taking Note of Notary Employees: Employer Liability for Notary Employee Misconduct. Me. L. Rev., 50, 23.

Steiner, H. J., Alston, P., \& Goodman, R. (2008). International human rights in context: law, politics, morals: text and materials. Oxford University Press, USA.

Undang-undang Nomor 2 Tahun 2014 tentang Perubahan atas UUJN Nomor 30 Tahun 2004.

Undang-undang Nomor 30 Tahun 2004 tentang Undang-Undang Jabatan Notaris.

\section{Copyrights}

Copyright for this article is retained by the author(s), with first publication rights granted to the journal.

This is an open-access article distributed under the terms and conditions of the Creative Commons Attribution license (http://creativecommons.org/licenses/by/4.0/). 